\title{
The Biodiversity of Aquatic Gastropods in the Steppe Zone the West Siberian Plain (Western Siberia, Russia)
}

\author{
Elena A Serbina* \\ Institute of Systematics and Ecology of Animals SB RAS, Novosibirsk, Russia \\ *Corresponding author: Elena A Serbina, Institute of Systematics and Ecology of Animals SB RAS, Novosibirsk, Russia
}

\begin{abstract}
This study describes the species diversity, abundance and biomass of gastropods in the ecosystems of the southern part of Western Siberia (Karasukskii district, Novosibirsk Oblast). Distribution and Quantitative Characteristics of Common Species of Gastropoda are calculated. Twenty-one species of snails belonging to seven families were recorded, Lymnaeidae, Planorbidae, Bulinidae, Physidae, Bithynhdae, Succineidae, and Zonitidae. The biodiversity of mollusks was studied using the Shannon- Weaver index.
\end{abstract}

\section{Introduction}

The ecology of pond snails has been studied in the waterbodies of the central part of European Russia [1], but the authors emphasize the necessity of conducting similar studies in Siberia, and in other regions of our country. Gastropoda are widely distributed in the water bodies of the southern part of Western Siberia. They are an important component of benthic communities and take part in a number of trophic relationships. Some information about the ecology of freshwater snails' species is presented in the publications [2-4] but many aspects are still poorly studied. In particular, quantitative data on the communities of mollusks are scanty $[5,6]$. We, in a previous work [7] Jacquard index biodiversity gastropods are calculated. The aim of the present investigation was to identify the occurrence and distribution of freshwater snails in the lake, rivers systems from the steppe zone the West Siberian Plain.

\section{Materials and Methods}

The species composition and biomass of snails in August of 2009 were studied (Novosibirsk Oblast, south of Western Siberia). Samples were collected in different parts in the Karasuk River in the upstream(near the villages of Bystrukha N 54026' 53,2"; E 800 55' 50,5' and Chernovka N 540 09' 53,2"; E. 800 02' 54,2') and downstream near the villages of Gramotino and Sorochikha (N 500 45' 19,4'"; E. 780 20' 15,1' and N 530 43' 19,7'; E 770 56' 29,5'), and in six lakes of the Karasuk system: Astrodym N 53036' 59,4"; E 770 48' 04,7', Krivoye (reaches: Blagodatnoye N 530 49' 59,3"; E. 780 03' 17,3", Sopatoye N 530 48' 28,7"; E 78002' 18,5" and Gusinoye N 530 48' 13,0"; E 78004' 00,8”), Krotovo N 530 43' 30"; E 770 51' 31", Kusgan N 53044' 23"; E 770 53'25", Melkoye N 530 47' 37,9"; E 780 16'34,91", Titovo N 530 45' 25,8”; E 770 56'13,2".

The hydrological and hydrochemical characteristics of the rivers and lakes in steppe zone in the West - Siberian Plain are presented in the study by Savchenko (2010). The study was based at the Karasuk Field Station (Institute of Systematics and Ecology of Animals Russian Academy of Sciences; Karasukskii district, Novosibirsk region). Mollusks were collected according to the standard technique [8]. For a quantitative analysis of snails in the lake-river systems they were collected by hand from sites of $0.25 \mathrm{~m}^{2}$ (50x50 cm). The control sites were in open parts and in macrophyte stands at a depth of 0.1-1.1 m. To determine biomass, the collected mollusks were dried on a filter paper for $\geq 1 \mathrm{~min}$ and weighed. The species identification was made according to the shell and genital system using the keys $[9,10]$. The ICA index (index of copulatory apparatus) was one of the major criteria for the species definition of mollusks. The species definition within the Lymnaeidae index for mature specimens into account [6]. 


\section{Results}

\section{Species Composition of Gastropods}

In the Karasuk river - lakes system, of 21 species from 7 families of gastropods were recorded: Pond Snail - [Lymnaeidae]; Lymnaea (Radix) auricularia (L.,1758), L. (Peregriana) balthica (L., 1758); L. (P.) fontinalis (Studer, 1820), L. (P.) ovata (Drap., 1805), L. (P.) ampla (Hartmann, 1821), L. (P.) tumida (Held, 1836), and Lymnaea (Stagnicola) saridalensis (Mozley, 1934) and Great Pond
Snails (Lymnaea) stagnalis (L., 1758), L. (L.) fragilis (L., 1758), L. (L.) doriana (Bourguignat, 1862); Ramshorn snails, Planorbis planorbis (L., 1758), Anisus vortex (L., 1758), A. contortus (L.,1758), Segmentina nitida (Mull., 1774) [Planorbidae], and Planorbarius corneus (L., 1758) [Bulinidae]; Physa fontinalis (L., 1758), Aplexa nypnorum (L., 1758) [Physidae]; Bithynia tentaculata (L., 1758) and B. troscheli (Paasch, 1842) [Bithyniidae]. Terrestrial gastropods were defined by genus, Succinea sp. [Succineidae] and Zonitoides sp. [Zonitidae].

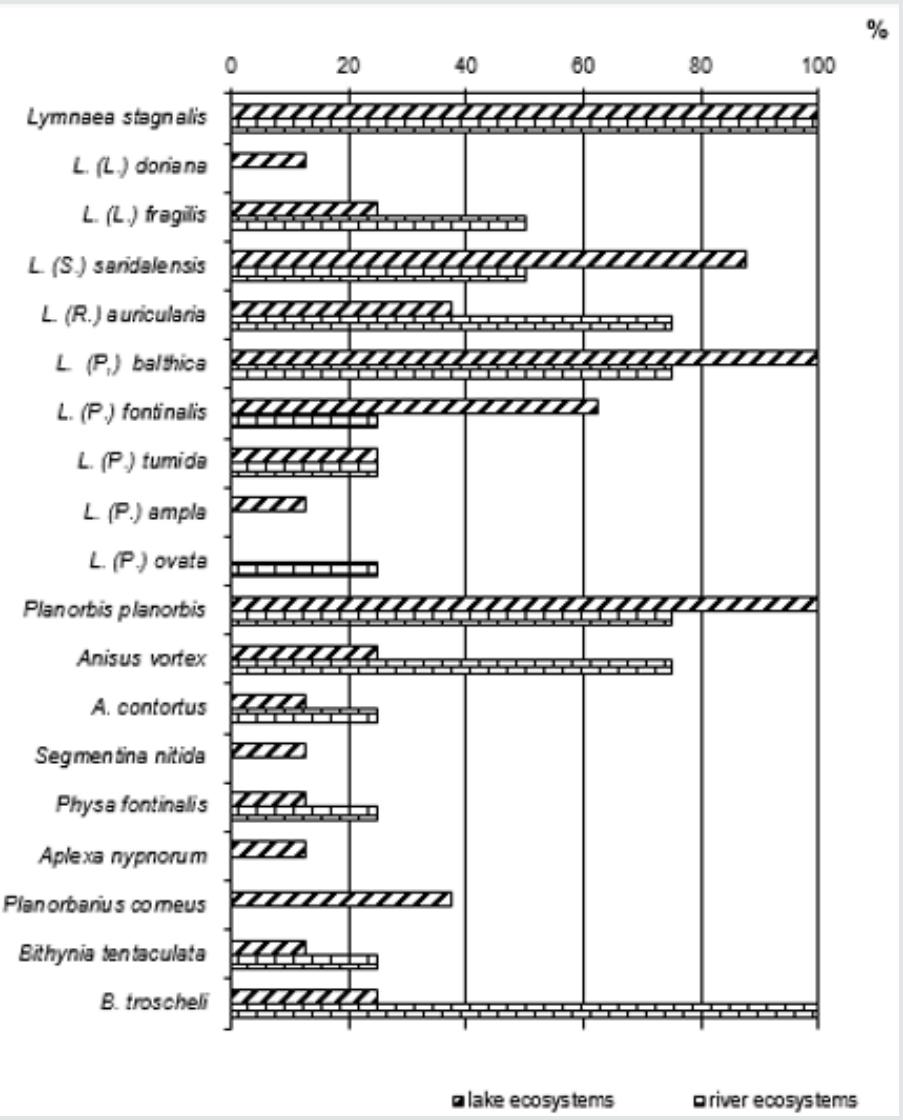

Figure 1: Distribution (\%) of gastropods in the Karasuk River and lakes of the Karasuk system.

Table 1: Abundance and biomass of gastropods and the Shannon index in water objects from the Karasuk system.

\begin{tabular}{|c|c|c|c|}
\hline Water Object & Abundance ind./m² & Biomass $\mathbf{g} / \mathbf{m}^{2}$ & Shannon Index \\
\hline Lakes: Astrodym & $0.02-55.0$ & $0.03-55.67$ & 1,472 \\
\hline Krotovo & $16.2-124.0$ & $5.05-84.02$ & 1,381 \\
\hline Kusgan & $0.04-92.0$ & $0.14-252.89$ & 0,561 \\
\hline Melkoye & $216.0-400.0$ & 144.00-369.79 & 1,440 \\
\hline Titovo & $106.0-252.0$ & $13.40-348.84$ & 1,982 \\
\hline Krivoye: reaches Blagodatnoye & $1.02-49.0$ & $1.24-9.41$ & 1,298 \\
\hline Sopatoye (Kuria) & $0.4-154.0$ & $0.80-85.62$ & 1,926 \\
\hline Gusinoye & $2.0-116.0$ & $4.48-96.59$ & 1,331 \\
\hline The Karasuk River near the villages: Bystrukha & $0.1-192.0$ & $1.27-21.69$ & 1,523 \\
\hline Chernovka & $0.3-31.0$ & $0.03-142.89$ & 1,462 \\
\hline Gramotino & $16.0-30.0$ & $21.46-30.55$ & 1,914 \\
\hline Sorochikha & $37.0-38.0$ & $14.85-76.62$ & 1,875 \\
\hline
\end{tabular}


Sixteen gastropod species were recorded in the river and 20 in the lakes (Figure 1). Fifteen species were common for both the river and the lakes. The snails L. (P.) ovata were found in the river only and five species were found only in the lakes: ( $L$. ( $L$.) doriana and $L$. (P.) ampla, only in the Astrodym lake; $S$. nitida only in the Krotovo lake; A. nypnorum only in the Melkoye lake). Ramshorn snails P. corneus were found in the Krivoye Krotovo and Titovo lakes. Gastropoda in modern freshwater water bodies (the steppe zone West Siberian Plain) are represented by Pulmonata and Prosobranchia species. Both secondary aquatic pulmonate snails (four families) and terrestrial species (two families) were recorded in the study area The terrestrial snails inhabit plants that grow close to the water's edge and appear in the samples of aquatic species. Prosobranchia snails are primarily aquatic; they are the most ancient colonizers of the continental water bodies and are represented by only one family, Bithyniidae. Both bithyniid snails were recorded only in the upper stream of the Karasuk River (close to Bystrukha Village) and in Krotovo Lake [11].

\section{Assessment of the Abundance and Biomass of Gastropods}

The abundance of snails in the river varied from 10 up to 192 ind./m² (Table 1). Lymnaeidae snails dominated, followed by Bithyniidae snails were sub-dominants. The Shannon-Weaver index, as calculated under the gastropod population density, indicated an increase of the species diversity from 1.4-1.5 bit/ind. (upper stream) up to 1.8-1.9 bit/ind. (lower stream). The maximum abundance of snails in the lakes varied from 49 up to $400 \mathrm{ind} . / \mathrm{m}^{2}$. (Blagodatnoye reach and Melkoye). In lakes the Shannon-Weaver index varied from $0.56 \mathrm{bit} / \mathrm{ind}$. (Kusgan) up to $1.9 \mathrm{bit} / \mathrm{ind}$. (Titovo; Sopatoye reach). The maximum biomass of gastropods in the river varied from 21.7 to $142.9 \mathrm{~g} / \mathrm{m}^{2}$; or in lakes from 9.4 to $369.8 \mathrm{~g} /$ $\mathrm{m}^{2}$ (Blagodatnoye reach and Melkoye). Lymnaeidae snail's biomass were dominated by, both in the river and in the lakes [12,13]. It should be mentioned that high abundance did not always correlate with high biomass. Thus, the high abundance (192 ind./ $\mathrm{m}^{2}$ ) of L. stagnalis corresponded to the biomass $1.26 \mathrm{~g} / \mathrm{m}^{2}$, which can be explained by the prevalence of young snails in the samples. Although an adult $L$. stagnalis can weigh 4.9 grams.

Twenty-one species of snails belonging to seven families were recorded, Lymnaeidae, Planorbidae. Bulinidae, Physidae, Bithynhdae, Succineidae, and Zonitidae. All the recorded mollusk species are common in water bodies that are characterized by slow cur rents, in stagnant (mostly perennial) and semilotic water pools; they are common species in the southern part of Western Siberia. Lymnaeidae snail's biomass were dominated by, both in the river and in the lakes.

\section{Acknowledgement}

The study was supported by the Federal Fundamental Scientific Research Programme for 2013-2020. Project numaber: AAAA-A16-116121410121-7.

\section{References}

1. Berezkina GV, Starobogatov YaI (1998) Ekologiya razmnozheniya i kladki yaits presnovodnykh legochnykh mollyuskov (Ecology of Breeding and Egg Clusters by Freshwater Pulmonary Mollusks), Leningrad: Zool. Inst. AN SSSR.

2. Sipko LL (1982) Aquatic Vegetation, Zooplankton and Zoobenthos of Lakes of the Karasuk System, in Opyt kompleksnogo izucheniya 1 ispol'zovaniya Karasukskikh ozer (An Experience of Multidisciplinary Study and Use of Karasuk Lakes). Novosibirsk: Nauka, Russia pp. 80-119.

3. Dolgin VN (2001) Freshwater Mollusks of Subarctic and Arctic Regions of Siberia, Doctoral (Biol.) Dissertation, Tomsk, Russia.

4. Serbina EA, Vodyanitskaya SN (2010) Gastropods, in Bioraznoobrazie Karasuksko-Burlinskogo regiona (Zapadnaya Sibir') (Biodiversity of the Karasuk-Burla Region (Western Siberia)). Novosibirsk: Nauka, Russia pp. 124-131.

5. Serbina EA (2010) Quantitative Estimation of Species Composition and Biomass of Gastropods in Lake Krivoe (Southern Part of Western Siberia, Russia) Biol. Nauki Kazakhstana 3: 46-53.

6. Serbina EA (2013) A quantitative estimation of the role of Bithyniidae snails (Gastropoda: Prosobranchia) in the ecosystems of the southern part of Western Siberia (Russia). Contemporary Problems of Ecology 6(1): 28-33.

7. Mosina MA, Serbina EA (2017) Biodiversity gastropods in Karasuk lakesriver systems (Western Siberia, Russia): Modern problems of evolution and ecology. XXII Lyubishchevskie, Ulyanovsk University, Russia pp. 330333.

8. Zhadin VI (1952) Mollusks of Fresh and Brackish Waters of the USSR, in Opredelitel' po faune SSSR (Identification Guide to the Fauna of the USSR), Moscow: Sovetskaya nauka, Russia, 46.

9. Starobogatov Ya I, Prozorova LA, Bogatov VV, Saenko EM (2004) Opredelitel' presnovodnykh bespozvonochnykh Rossii i sopredel'nykh territorii (Identification Key to the Freshwater Invertebrates in Russia and Adjacent Territories). St. Petersburg: Nauka, Russia 6: 6-491.

10. Rastyazhenko NM, Serbina E A (2015) Number and a biomass pond snails (Pulmonata, Lymnaeidae) from Karasuk lake-river system (the south of Western Siberia): Modern problems of evolution and ecology. XXII Lyubishchevskie, Ulyanovsk University, Russia pp.464-467.

11. Vinarski MV, Serbina EA (2012) Distribution and Quantitative Characteristics of Common Species of Pond Snails of the Subgenera Peregriana and Radix (Mollusca: Gastropoda: Lymnaeidae) in Waterbodies of the South of Western Siberia. Inland Water Biology 5(2): 192-198.

12. Serbina EA (2012) Number and biomass Lymnaea stagnalis (Gastropoda, Lymnaeidae) in the ecosystems of the south of Western Siberia (Russia). Volodymyr Hnatyuk: Biology 2 (51): 227-230.

13. Kruglov ND (2005) Mollyuski semeistva prudovikov (Lymnaeidae, Gastropoda, Pulmonata) Evropy i Severnoi Azii (osobennosti ekologii i parazitologicheskoe znachenie) (Mollusks of the Family Lymnaeidae (Gastropoda,Pulmonata) in Europe and North Asia (Characteristics of Ecology and Parasitological Role)). Smolensk: Izd Smolensk Gos Ped Univ, Russia. 
(C) (i) This work is licensed under Creative

BY Submit Your Article Click Here• Submit Article

DOI: 10.32474/OAJESS.2019.02.000130

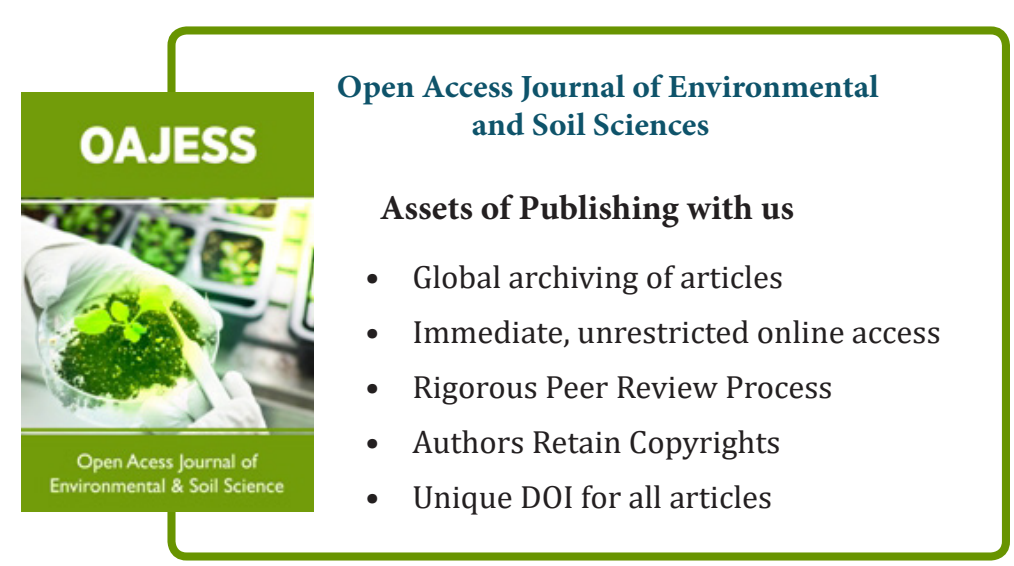

